\title{
Effect of Water Acidification and Sanitation on Performance, Gut Microbial Population and Carcass Characteristics of Broiler Chicken
}

\author{
Sheikh Adil*, Mohamad Tufail Banday, Islam Uddin Sheikh, Azmat Alam Khan, Irfan Akram Baba and Bushra Zaffer \\ Division of Livestock Production and Management, Faculty of Veterinary Sciences and Animal Husbandry, Sher-e-Kashmir University of Agricultural \\ Sciences and Technology of Kashmir, Shuhama, Srinagar-190006, India \\ *Corresponding author’s Email: aadilsheikh5@gmail.com; ORCID: 0000-0003-0871-1133
}

Received: 05 May 2020

Accepted: 13 June 2020

\begin{abstract}
Management of water is of utmost importance in order to ensure better performance of poultry birds. A study was thus conducted to evaluate the effect of water acidification and sanitation on performance, gut microbial population and carcass characteristics of broiler chicken. A total of 144 broiler chickens aged one-week were utilized for the study up to 6 weeks of age. The birds were distributed into 4 treatment groups of three replicates of 12 chickens. Untreated drinking water was routinely used in the control group (T1). In T2 and T3, acidifier and sanitizer were used in an amount of $1 \mathrm{ml}$ and $5 \mathrm{ml} / 20$ liters of water, respectively, while in T4 a combination of acidifier and sanitizer was used in similar doses. There was a significant effect of acidification and sanitization of water on body weight gain and feed conversion ratio of broiler chicken. The combination of acidifier and sanitizer (T4) was found to be highly effective in improving chickens' performance, followed by sanitizer alone (T3) and acidifier alone (T2), compared to the control group. There was no significant effect on various carcass characteristics of broiler chicken except for the gut $\mathrm{pH}$ and intestinal length. There was a significant effect on the $\mathrm{pH}$ value of various intestinal segments in broiler chickens using acidifier treated water (T2) compared to T1 and T3, but no statistical effect was noticed between T2and T4. A similar trend was noticed in the length of intestines of broiler chickens in various treatment groups. There was a significant reduction in Caecal Coliform Count ( in all the treatment groups that was used acidifier and sanitizer compared to the control group.
\end{abstract}

Key words: Acidifier, Broiler chicken, Gut microbiology, Performance, Sanitizer

\section{INTRODUCTION}

It has been estimated that there will be a lack of clean water in almost half of the world by 2025 (Micciche et al., 2018). Water is the most important nutrient and is physiologically required in all animals, including poultry. Therefore, the quantity and quality of water should be supplied daily according to the age and breed of the birds to maintain all physiological functions. Moreover, from a health perspective, the amount of water consumed on a daily basis by commercial poultry birds is considered as a prime indicator (Manning et al., 2007). In addition to the production perspective, providing adequate and good quality water is listed as a basic animal welfare criterion (NCC, 2010).

The use of acidifiers in poultry is relatively new. Almost all acidifiers were considered safe for animal use (Center for Food Safety Applied Nutrition, 2018). A wide range of acidifiers with variable physical and chemical properties are available for poultry, many of which are used in the drinking water or mixed with the feed (Huyghebaertet al., 2011; Menconi et al., 2014). It has been documented that the use of acidifiers benefit the young chickens by their role in competitive exclusion, improving intestinal health and nutrient utilization, and the performance of birds (Adil et al., 2010; Saki et al., 2012). The acidifiers penetrate the cell wall of certain bacteria in non-dissociated form and disrupt their physiology (Dhawale, 2005). Besides antimicrobial activity, acidifiers decrease gut $\mathrm{pH}$, increase secretions from pancreas and exert trophic impact on mucosa of gastro-intestinal tract (Dibner and Buttin, 2002).

Sanitizers such as quaternary ammonium compounds are also used in poultry operation to disinfect the water and water system (Schwartz, 1994). Biofilm formation exposes birds to various pathogens (Maharjan et al., 2017). The oxidability of these chemicals in water destroyed most bacteria and viruses within a few seconds (Yang, 2006) 
and maintained the biologically safe and stable environment in the water, which prevented the regrowth of microbes, algal blooms and biofilm formation in the water distribution systems (Sparks, 2009). Daily water sanitation at poultry farms had improved the performance and profitability of poultry birds (Tablante et al., 2002).

In view of the beneficial effects of acidifiers and sanitizers and the scares literature available on the use of a combination of acidifiers and sanitizers in poultry production, the present study was undertaken.

\section{MATERIALS AND METHODS}

\section{Ethical approval}

The present study was approved by the Institutional Animal Ethics Committee after approval in Research Council Meeting of SKUAST-Kashmir, India.

\section{Methodology and Experimental design}

The study was carried out using144 commercial Cobb straight broiler chickens, purchased from local supplier. On arrival of day old birds, they were offered sugar solution (8\%) and ground maize for initial 12 hours. In order to avoid stress, the water-soluble vitamins and electrolytes were added to the drinking water in the first 3 days. At the age of 7 days, the chickens were divided into 4 treatment groups with 3 replicates of 12 chickens. The 24 hours lighting schedule was maintained and exhaust fans were used for proper ventilation. The birds were vaccinated against New castle and Gumboro diseases. Fresh food and water were provided ad libitum daily. The feeding program consisted of a starter diet up to 21 days and a grower diet up to the age of 42 days for all broiler chickens. Untreated drinking water was used routinely in the control group (T1). In T2 and T3 groups, acidifier and sanitizer were used in the amount of $1 \mathrm{ml}$ and $5 \mathrm{ml} / 20$ liters of water respectively, while in $\mathrm{T} 4$ group a combination of acidifier and sanitizer at similar doses was used.

\section{Parameters recorded}

The body weight and feed intake per replicate were recorded weekly and subsequently the feed conversion ratio per replicate was determined. After the completion of the trail, 6 days were randomly selected and slaughtered from each treatment. The length of gastrointestinal tract was measured with a tape measure. The intestine was exposed on both sides. The carcass characteristics were evaluated. The contents of caeca were collected, weighed ( 1 gram), and then homogenized in sterile tubes in the ration $1: 1$ with $0.9 \%$ normal saline solution. Then the solutions were mixed on vortex. Serial dilutions of the samples were made up to the sixth dilution. $0.1 \mathrm{ml}$ was withdrawn from each dilution, and distributed evenlyon Brain Heart Infusion (BHI) agar and the caecal coliforms count was calculated. The plates were incubated at $37^{\circ} \mathrm{C}$ for 48 hours. Bacterial colonies were counted by the pour plate method (Quinn et al., 1992). The average number of colonies was multiplied by reciprocal of the dilution factor and expressed as cfu/gram of contents.

\section{Statistical analysis}

The data obtained were statistically assessed by the analysis of variance (ANOVA) through the General Linear Model procedure of SPSS (20.0) software, considering replicates as experimental units. The values were expressed as means \pm Standard Error (SE). Duncan's multiple range test was used to test the significance of the difference between the means by considering the significant differences at $\mathrm{p}<0.05$.

\section{RESULTS AND DISCUSSION}

The feed consumption showed no statistical difference ( $>0.05)$ between the treatment groups compared to the control group (Table 1). These results were in agreement with the results of Banday et al. (2015), who found no difference in the cumulative feed consumption between the groups in which acidifiers were used and the control group. There was a significant $(\mathrm{p}<0.05)$ improvement in the chickens FCR using acidifier and sanitizer in water alone or in combination compared to the control group (Table 2). The combination of acidifier and sanitizer (T4) was found to be highly effective in improving the chickens FCR, followed by sanitizer alone (T3) and acidifier alone (T2) compared to the control group (T1). The improvement in the FCR could possibly be due to better use of nutrients, which leads to in increased body weight gain in the birds (as can also be seen in the present study), since the water was used based on acidifying and sanitizer agents. These results were consistent with other researchers (Adil et al., 2011; Sultan et al. 2014; Banday et al., 2015), who reported that the addition of acidifiers and sanitizers improved the feed conversion ratio in poultry birds.

The body weight gains were significantly $(\mathrm{p}<0.05)$ improved by addition of acidifier and sanitizer alone or in combination in water of broiler chicken compared to the control group (Table 3). The combination of acidifier and sanitizer (T4) was found highly effective in improving the body weight gains of broiler chicken, followed by sanitizer 
alone (T3) and acidifier alone (T2) compared to control group (T1). The results of present study regarding acidifier coincides with the results of other researchers (Aoet al., 2009; Adil et al., 2011; Banday et al., 2015) who reported that the supplementation of acidifiers improves the body weight gain in poultry birds compared to control group. Likewise, Tablante et al. (2002) and Jacobs et al. (2019) reported that water sanitation improved the performance of poultry.

Table 1.Feed consumption of cobb broiler chickens in different treatments wherein acidifiers and sanitizers used in water in 2019 at the farm of Faculty of Veterinary Sciences SKUAST-K in Kashmir region, India

\begin{tabular}{lcccc}
\hline \multirow{2}{*}{ Age } & \multicolumn{4}{c}{ Treatment Groups } \\
\cline { 2 - 5 } & T1 (control group) & T2 (Acidifier) & T3 (Sanitizer) & T4 (Acidifier + Sanitizer) \\
\hline 1-2 weeks & $276.13 \pm 0.9^{*}$ & $273.67 \pm 1.6$ & $272.26 \pm 1.3$ & $273.11 \pm 4.9$ \\
2-3 weeks & $508.05 \pm 6$ & $537.27 \pm 18.6$ & $532.56 \pm 12.1$ & $548.01 \pm 13.1$ \\
$1-4$ weeks & $1190.39 \pm 31.2$ & $1209.58 \pm 37.7$ & $1213.44 \pm 25.4$ & $1221.14 \pm 41.8$ \\
$1-5$ weeks & $2054.41 \pm 55.7$ & $2065.50 \pm 13.8$ & $2082.25 \pm 51.2$ & $2071.78 \pm 61.4$ \\
$1-6$ weeks & $3183.16 \pm 95$. & $3149.83 \pm 80.7$ & $3172.06 \pm 52.7$ & $3238.80 \pm 90.1$ \\
\hline
\end{tabular}

*: means \pm standard error

Table 2.Feed conversion ratio of Cobb broiler chickens in different treatments wherein acidifiers and sanitizers were used in water in 2019 at the farm of Faculty of Veterinary Sciences SKUAST-K in Kashmir region, India

\begin{tabular}{lcccc}
\hline \multirow{2}{*}{ Age } & \multicolumn{4}{c}{ Treatment Groups } \\
\cline { 2 - 5 } & T1 (control group) & T2 (Acidifier) & T3 (Sanitizer) & T4 (Acidifier+ Sanitizer) \\
\hline 1-2 weeks & $1.39^{\mathrm{a}} \pm 0.06$ & $1.38^{\mathrm{a}} \pm 0.05$ & $1.38^{\mathrm{a}} \pm 0.01$ & $1.37^{\mathrm{a}} \pm 0.01$ \\
2-3 weeks & $1.54^{\mathrm{b}} \pm 0.11$ & $1.45^{\mathrm{a}} \pm 0.17$ & $1.43^{\mathrm{a}} \pm 0.12$ & $1.41^{\mathrm{a}} \pm 0.17$ \\
$1-4$ weeks & $1.68^{\mathrm{b}} \pm 0.17$ & $1.56^{\mathrm{a}} \pm 0.23$ & $1.52^{\mathrm{a}} \pm 0.13$ & $1.50^{\mathrm{a}} \pm 0.16$ \\
$1-5$ weeks & $1.83^{\mathrm{b}} \pm 0.01$ & $1.73^{\mathrm{a}} \pm 0.02$ & $1.71^{\mathrm{a}} \pm 0.02$ & $1.68^{\mathrm{a}} \pm 0.03$ \\
1- 6 weeks & $1.96^{\mathrm{b}} \pm 0.34$ & $1.84^{\mathrm{a}} \pm 0.03$ & $1.82^{\mathrm{a}} \pm 0.01$ & $1.80^{\mathrm{a}} \pm 0.03$ \\
\hline $\mathrm{a}, \mathrm{b}$
\end{tabular}

$\overline{\mathrm{a}, \mathrm{b}}=$ Means within the same row with different superscripts are significantly different $(\mathrm{p}<0.05) ;{ }^{*}$ : means \pm standard error

Table 3.Body weight gain of Cobb broiler chickens in different treatments wherein acidifiers and sanitizers were used in water in 2019 at the farm of Faculty of Veterinary Sciences SKUAST-K in Kashmir region, India

\begin{tabular}{lcccc}
\hline \multirow{2}{*}{ Age } & \multicolumn{4}{c}{ Treatment Groups } \\
\cline { 2 - 5 } & T1 (control group) & T2 (Acidifier) & T3 (Sanitizer) & T4 (Acidifier+ Sanitizer) \\
\hline $1-2$ weeks & $198.65^{\mathrm{a}} \pm 1.4$ & $198.32^{\mathrm{a}} \pm 2$ & $197.47^{\mathrm{a}} \pm 2.4$ & $199.33^{\mathrm{a}} \pm 2.848$ \\
2-3 weeks & $330.0^{\mathrm{b}} \pm 6.3$ & $370.21^{\mathrm{a}} \pm 8.3$ & $372.28^{\mathrm{a}} \pm 5.5$ & $388.39^{\mathrm{a}} \pm 8.2$ \\
$1-4$ weeks & $708.50^{\mathrm{b}} \pm 11.2$ & $775.17^{\mathrm{a}} \pm 12.7$ & $798.85^{\mathrm{a}} \pm 22.8$ & $813.31^{\mathrm{a}} \pm 18.5$ \\
$1-5$ weeks & $1122.74^{\mathrm{b}} \pm 23.3$ & $1194.29^{\mathrm{a}} \pm 19.9$ & $1217.41^{\mathrm{a}} \pm 17.6$ & $1232.28^{\mathrm{a}} \pm 19.7$ \\
$1-6$ weeks & $1623.89^{\mathrm{c}} \pm 30$ & $1711.0^{\mathrm{b}} \pm 17$ & $1742.81^{\mathrm{ab}} \pm 17.9$ & $1798.56^{\mathrm{a}} \pm 21.4$ \\
\hline
\end{tabular}

$\overline{\mathrm{a}, \mathrm{b}}=$ Means within the same row with different superscripts are significantly different $(\mathrm{p}<0.05) ;{ }^{*}$ : means \pm standard error

Table4.Carcass characteristics, gut $\mathrm{pH}$ and gut microbiology of Cobb broiler chickens offered water treated with acidifier and sanitizer in 2019 at the farm of Faculty of Veterinary Sciences SKUAST-K in Kashmir region, India

\begin{tabular}{lcccc}
\hline Parameters & $\begin{array}{c}\text { T1 } \\
\text { (Control) }\end{array}$ & $\begin{array}{c}\text { T2 } \\
\text { (Acidifier) }\end{array}$ & $\begin{array}{c}\text { T3 } \\
\text { (Sanitizer) }\end{array}$ & $\begin{array}{c}\text { T4 } \\
\text { (Acidifier +Sanitizer) }\end{array}$ \\
\hline Dressing percentage & $71.23^{\mathrm{a}} \pm 0.51$ & $70.44^{\mathrm{a}} \pm 0.79$ & $72.67^{\mathrm{a}} \pm 1.31$ & $71.34^{\mathrm{a}} \pm 1.17$ \\
Ready to cook yield (\%) & $75.28^{\mathrm{a}} \pm 1.05$ & $75.45^{\mathrm{a}} \pm 0.82$ & $76.19^{\mathrm{a}} \pm 0.69$ & $76.32^{\mathrm{a}} \pm 0.58$ \\
Length of small intestine (cm) & $168.43^{\mathrm{a}} \pm 1.57$ & $179.30^{\mathrm{b}} \pm 2.04$ & $169.52^{\mathrm{a}} \pm 2.13$ & $179.95^{\mathrm{b}} \pm 1.76$ \\
Weight of small intestine (g) & $41.62^{\mathrm{a}} \pm 0.93$ & $47.23^{\mathrm{b}} \pm 1.12$ & $40.66^{\mathrm{a}} \pm 1.01$ & $46.85^{\mathrm{b}} \pm 1.27$ \\
Crop pH & $4.83^{\mathrm{a}} \pm 0.02$ & $4.57^{\mathrm{b}} \pm 0.03$ & $4.99^{\mathrm{c}} \pm 0.01$ & $4.54^{\mathrm{b}} \pm 0.02$ \\
Duodenum pH & $5.71^{\mathrm{a}} \pm 0.01$ & $5.45^{\mathrm{b}} \pm 0.02$ & $5.79^{\mathrm{a}} \pm 0.03$ & $5.46^{\mathrm{b}} \pm 0.01$ \\
Caecal coliform count & $5.64^{\mathrm{a}} \pm 0.04$ & $5.03^{\mathrm{b}} \pm 0.01$ & $5.11^{\mathrm{b}} \pm 0.01$ & $5.08^{\mathrm{b}} \pm 0.02$ \\
\hline
\end{tabular}




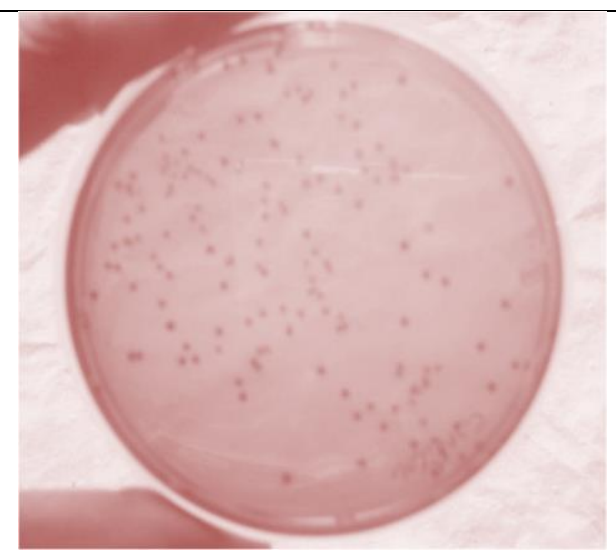

Control (T1)

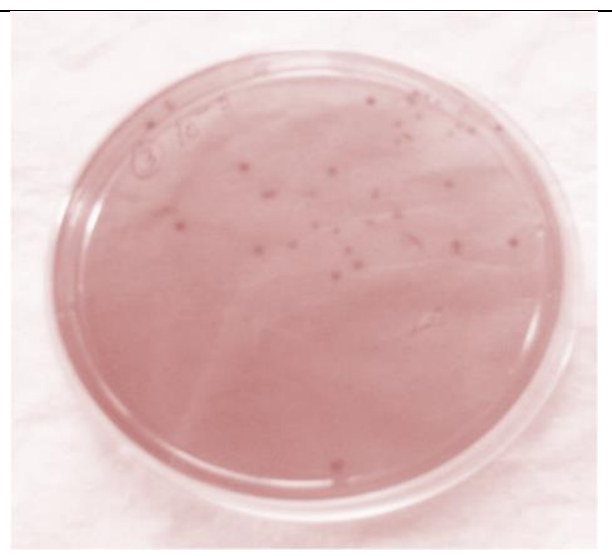

Acidifier (T2)

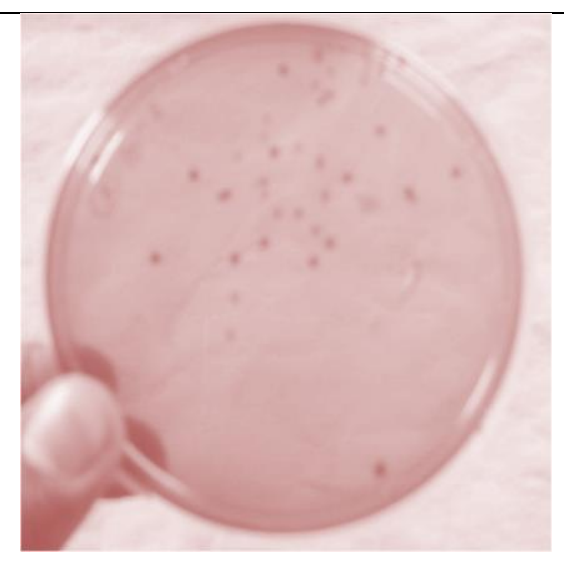

Sanitizer (T3)

Figure 1. The effect of acidifiers and sanitizers in water on caecal coliform count of broiler chickens at the farm of Faculty of Veterinary Sciences SKUAST-K in Kashmir region, India

The improved body weight gain due to addition of acidifiers and sanitizers in water is probably due to the beneficial effect on gut flora as observed in the present study because of reduced caecal coliform count, reduced gut $\mathrm{pH}$ and beneficial effect on intestinal morphology (Table 4 and figure 1). A significant reduction in caecal coliform count in all the treatment groups was observed wherein acidifier and sanitizer treated was used when compared to control. The combination of acidifier and sanitizer (T4) was found highly effective in reducing the caecal coliform count. Similar results were observed by Adil et al. 2011 and Owens et al. (2008) who reported significant $(\mathrm{p}<0.05)$ reduction in total viable caecal coliforms in broiler chicken as a result of acidifier supplementation. A significant decrease in the number of total and gram-negative bacteria has been reported when using acidifiers (Gunal et al., 2006). Samanta et al. (2010) also reported that acidifiers reduce E. coli and other harmful bacteria which mayenhance poultry growth. Antibacterial effect of acidifiers has been associated with the fact that undissociated organic acids pass through the cell membrane of the bacteria and afterward dissociate forming $\mathrm{H}^{+}$ions and this, in turn, decreases the $\mathrm{pH}$ value ofthe bacterial cell. In order to restore the normal balance, bacteria use its energy. Whereas RCOO- anions produced from the acid can disrupt DNA, hampering protein synthesis and putting the organism in stress. As a result the organism cannot multiply rapidly and decrease in number Nursey (1997). Similarly, sanitizers have been reported to control microbes or inhibit biofilm formation because of antimicrobial activity (Maharjan et al., 2016). Because of antibacterial activity of acidifiers and sanitizers, there would have been a decrease in the competition for the host nutrients, thereby improving the protein and energy digestibility and subsequent overall performance of the broiler chickens.

Further, this antibacterial activity gets augmented by $\mathrm{pH}$ reducing property of acidifiers as was seen in the present study (Table 4). The use of acidifiers resulted in decreased $(\mathrm{p}<0.05) \mathrm{pH}$ in crop and duodenum of broiler chicken. The reduced $\mathrm{pH}$ is helpful for the growth of favorable bacteria and at the same time prevented the growth of harmful bacteria which require a relatively higher $\mathrm{pH}$ for growth (Adil et al., 2011). Moreover, no effect ( $p>0.05)$ on carcass characteristics was observed as a result of addition of acidifiers and sanitizers in drinking water of broiler chicken except for the weight and length of small intestine (Table 4). There was a significant $(\mathrm{p}<0.05)$ effect on $\mathrm{pH}$ value of various segments of gut in broiler chicken wherein acidifier treated water $\left(T_{2}\right)$ was used when compared to $T_{1}$ and $T_{3}$, however no statistical effect was noticed between $T_{2}$ and $T_{4}$. Similar trend was noticed in the length of intestines of broiler chicken among various treatment groups. Adil et al. (2011) also reported that acidifiers resulted in remarkable increase in the intestinal weight and length of broiler chicken. These results could be attributed to the fact that acidifiers have direct stimulatory effect on the gastro-intestinal cell proliferation as was reported by other workers with short chain fatty acids. The short chain fatty acids are believed to increase plasma glucagon-like peptide 2 (GLP-2) and ileal pro-glucagon mRNA, glucose transporter (GLUT2) 
expression and protein expression, which are all signals which can potentially mediate gut epithelial cell proliferation Tappenden and McBurney (1998). Le Blay et al. (2000) and Fukunaga et al. (2003) also reported that short chain fatty acids can accelerate gut epithelial cell proliferation, thereby increase improve intestinal morphology. Besides antibacterial activity, this improved intestinal morphology effect augments performance of birds by improved digestion of nutrients.

\section{CONCLUSION}

In conclusion, addition of acidifiers and sanitizers @ 1ml and $5 \mathrm{ml} / 20$ liters of water of broiler chickens improve their performance and subsequent profitability out of a poultry enterprise. The beneficial effects were achieved by antibacterial and improved gut health properties of acidifiers and sanitizers, it is thus recommended to improve the quality of water at poultry farms by adding acidifier and sanitizer products.

\section{DECLARATIONS}

\section{Acknowledgements}

The authors are highly grateful to the Head Division of LPM, SKUAST-K, for financial support during the study.

\section{Competing interests}

The authors declare that they have no competing interests.

\section{Author's contributions}

MT Banday and IU Sheikh designed the research; S Adil performed the research and wrote the manuscript; IA Baba and B Zafferassisted in collection of data and AA Khan analysed the data. All authors read and approved the final version of the manuscript.

\section{Consent to publish}

All the authors gave their informed consent prior to their inclusion in the study.

\section{REFERENCES}

Adil S, Banday MT, Bhat GA, Mir MS, and Rehman M (2010). Effect of dietary supplementation of organic acids on performance, intestinal, histomorphology, and serum biochemistry of broiler chicken. Veterianry Medicine International, 1-7. DOI: https://doi.org/10.4061/2010/479485

Adil S, Banday MT, Bhat GA, Qureshi SD, and Wani SA (2011). Effect of supplemental organic acids on growth performance and gut microbial population of broiler chicken. Livestock Research for
Rural Development, 23:1-7. Available at:http://www.lrrd.org/lrrd23/1/adil23006.htm

Ao T, Cantor AH, Pescatore AJ, Ford MJ, Pierce JL, and Dawson KA (2009). Effect of enzyme supplementation, and acidification of diets on nutrient digestibility and growth performance of broiler chicks. Poultry $\quad$ Science, 88: 111-117. DOI:https://doi.org/10.3382/ps.2008-00191

Banday MT, Adil S, Khan AA, and Untoo M (2015). Study on efficacy of fumaric acid supplementation in diet of broiler chicken. International Journal of Poultry Science, 14 (11): 589-594. Available at:https://scialert.net/abstract/?doi=ijps.2015.589.594

Center for Food Safety and Applied Nutrition (2018). GRAS Substances (SCOGS) Database. Available at: https://www.fda.gov/food/ ingredients packaging labeling/gras/scogs/default.htm

Dhawale A (2005). Better eggshell quality with a gutacidifier. Poultry International, $\quad 44$ : 18-21. Available at:http://stocarstvo.com/ishrana/Better_eggshell quality with_a gu t acidifier.htm

Dibner JJ, and Buttin P (2002). Use of organic acids asa model to study the impact of gut microflora onnutrition, and metabolism. Journal of Applied Poultry Research, 11:453-463. DOI:https://doi.org/10.1093/japr/11.4.453

Fukunaga TM, Sasaki Y, Araki T, Okamoto T, Yasuoka T, Tsujikawa, Fujiyama Y, and Bamba T (2003). Effects of the soluble fibre pectin on intestinalcell proliferation, fecal short chain fatty acidproduction and microbial population. Digestion, 67:42-49. DOI:https://doi.org/10.1159/000069705

Gunal M, Yayli G, Kaya O, Karahan N, and Sulak O (2006). The effects of antibiotic growth promoter, probiotic, or organic acid supplementation on performance, intestinal microflora, and tissue of broilers. International Journal of Poultry Science, 5: 149-155. Available at: https://scialert.net/abstract/?doi=ijps.2006.149.155

Huyghebaert G, DucatelleR,and Van Immerseel F (2011). An update on alternatives to antimicrobial growth promoters for broilers. $\begin{array}{llll}\text { Veterinary } & \text { Journal, } & 182-188 .\end{array}$ DOI:https://doi.org/10.1016/j.tvj1.2010.03.003

Jacobs L, Persia ME, Siman-Tov N, McCoy J, Ahmad M, Lyman J, and Good L (2019). Impact of water sanitation on broiler chicken production and welfare parameters. Journal of Applied Poultry Research, 29(1);
DOI-https//doi org/10.1016/j japr 2019 10.013

LeBlay G, Blottiere HM, Ferrier L, LeFoll EC, Bonnet JP, Galmiche, and Cherbut C (2000). Shortchainfatty acids induce cytoskeletal and extracellular protein modification associated with modulation of proliferation on primary culture of rat intestinal smooth muscle cells. Digestive Diseases and Sciences, 45:16231630.DOI:https://doi.org/10.1023/A:1005529414765

Manning L, Chadd SA, and Baines RN ( 2007). Key health and welfare indicators for broiler production. World's Poultry Science Journal, 63 (1): 46-62. DOI:https://doi.org/10.1017/S0043933907001262

Maharjan P, Clark T, Kuenzel C, Foy MK, and Watkins S (2016). On farm monitoring of the impact of water system sanitation on microbial levels in broiler house water supplies. The Journal of

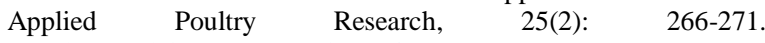
DOI:https://doi.org/10.3382/japr/pfw010

Maharjan P, Huff G, Zhang W, and Watkins S (2017). Effects of chlorine and hydrogen peroxide sanitation in low bacterial content water on biofilm formation model of poultry brooding house waterlines. Poultry Science, 96:2145-2150. DOI:https://doi.org/10.3382/ps/pex009

Menconi A, Kuttappan VA, Hernandez-Velasco X, Urbano T, Matté F, Layton S, Kallapura G, Latorre J, Morales BE, and Prado O et al. (2014). Evaluation of a commercially available organic acid product on body weight loss, carcass yield, andmeat quality during preslaughter feed withdrawal inbroiler chickens: a poultry welfare 
and economic perspective. Poultry Scinece, 93: 448-455. DOI:https://doi.org/10.3382/ps.2013-03444

Micciche AC, Feye KM, Rubinelli PM, Wages JA, Knueven C, and Ricke SC (2018). The implementation and food safety issues associated with poultry processing reuse water for conventional poultry production systems in the United States. Frontiers in $\begin{array}{lllll}\text { Sustainable Food } & \text { Systems, } & \text { 2: } & \text { DOI: }\end{array}$ https://doi.org/10.3389/fsufs.2018.00070

National Chicken Council (NCC) (2010). Animal Welfare Guidelines and Audit Checklist for Broiler. Washington DC. USA. Available at:https://www.nationalchickencouncil.org/

Nursey I (1997).Control of Salmonella. Kraftfutter, 10: 415-22. Available at:https://ci.nii.ac.jp/naid/10019768285/

Owens B, Tucker L, Collins MA, and McCracken KJ (2008). Effects of different feed additives alone or in combination on broiler performance, gut micro flora and ileal histology. British Poultry Science, 49(2): 202-12. DOI:https://doi.org/10.1080/00071660802004890

Quinn PJ, Carter ME, Markey BK, and Carter GR (1992).Mosby-year bookEurope limited Lynton House, 7-12 Tavistock square, London. Clinical Veterinary Microbiology, pp. 61-65. Available at:https://www.elsevier.com/catalog/veterinary-science-andveterinary-medicine/basic-science

Saki AA, Harcini RN, Rahmatnejad E, and Salary J (2012). Herbal additives and organic acids asantibiotic alternatives in broiler chickens diet for organic production. African Journal of Biotechnology, 11: 2139-2145. Available at:https://www.ajol.info/index.php/ajb/article/view/100474

Samanta S, Haldar S, and Ghosh TK (2010). Comparative efficacy of an organic acid blend and bacitracin methylene disalicylate as growth promoters in broiler chickens: effects on performance, gut histology, and small intestinal milieu. Veterinary Medicine International, 645-650. DOI:https://doi.org/10.4061/2010/645150

Schwartz LD (1994). Poultry Health Handbook, Penn State.Available at:http://agris.fao.org/agrissearch/search.do?recordID=US201300056612

Sparks NHC (2009). The role of the water supply system in the infection and control of Campylobacter in chicken. World's Poultry Science Journal, 65: 459-473. DOI:https://doi.org/10.1017/S0043933909000324

Sultan A, Ullah I, Khan RU, ul Hassan Z, and Khan S (2014). Impact of chlorine dioxide as water acidifying agent on the performance, ileal microflora and intestinal histology in quails. Archiv Tierzucht, 57: 1-9. DOI:https://doi.org/10.7482/0003-9438-57-031

Tablante NL, Myint MS, Johnson YJ, Rhodes K, Colby M, and Hohenhaus G (2002). A survey of biosecurity practices as risk factors affecting broiler performance on the Delmarva Peninsula. Avian Diseases, 46 (3): 730-734. DOI:https://doi.org/10.1637/00052086(2002)046

Tappenden KA, and McBurney MI (1998). Systemic short-chain fatty acids rapidly alter gastrointestinal structure, function, and expression of early response genes. Digestive Diseases and Sciences, 43: 1526-1536. DOI:https://doi.org/10.1023/A:1018819032620

Yang H, SwemBL and Li Y (2006). The effect of $\mathrm{pH}$ on inactivation of pathogenic bacteria on fresh-cut lettuce by dipping treatment with electrolyzed water. Journal of Food Science, 68 (3): 1013-1017. DOI: https://doi.org/10.1111/j.1365-2621.2003.tb08280.x 